\title{
Een uitdagende studie
}

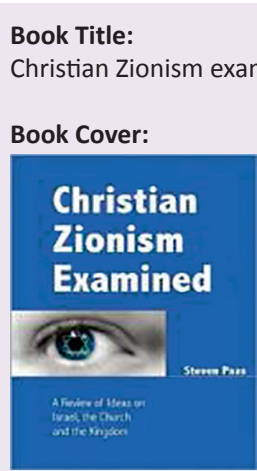

Author:

Steven Paas

ISBN:

978-3-941750-86-9

Publisher:

VTR Publications, 2012,

R206.30*

*Book price at time of review

-

Review Title:

Een uitdagende studie

Reviewer:

J. Kommers

\section{Affiliation:}

${ }^{1}$ Faculty of Theology,

North-West University,

Potchefstroom Campus,

South Africa

\section{Email:}

j.kommers777@gmail.com

\section{Postal address:}

Operadreef 94, 3845 GR

Harderwijk, Nederland

How to cite this book review: Kommers, J., 2015, 'Christian Zionism examined', In die Skriflig 49(1), Art. \#2038,

2 pages. http://dx.doi. org/10.4102/ids.v49i1.2038

\section{Copyright:}

(C) 2015. The Authors.

Licensee: AOSIS

OpenJournals. This work is

licensed under the Creative

Commons Attribution License.

\section{Read online:

Deze beknopte maar zeer inhoudsvolle studie levert een belangrijke bijdrage aan het gesprek over de positie van Israël binnen het Christelijk Zionisme. Het geeft in zeven hoofdstukken een historisch overzicht en beoordeling waarbij de auteur tot de conclusie komt dat er veel onjuistheden zitten in de benadering van het extreme gedachtegoed van christen-zionisten. De filosemitische, chiliastische visie op Israël van de afgelopen eeuwen passeert hier de revue. Wat onderzocht wordt is de sleutelrol die wordt toegekend aan het extreme Christen Zionisme met betrekking tot het hedendaagse staatkundige en etnische Israël en de plaats die om theologische redenen hier aan wordt gegeven met betrekking tot het heil (blz. 12).

Veel interessante exegetische doorkijkjes uit het Oude en Nieuwe Testament worden de lezer geboden. De wereldwijde reikwijdte van het heil voor Jood en heiden (de niet-Jood) wordt in de persoon van Melchizedek afgeschaduwd. De auteur komt dan tot de conclusie dat '[t]he demonstration of the universal scope of the offer of salvation does not imply the rejection of Israel but is linked to the continuing offer of salvation to Israel' (blz. 31). Nu is uitleg van de Schrift altijd op vooronderstellingen gebaseerd en gebeurt dit nooit in een vacuüm. Dat geldt ook voor de uitleg die de christen-zionisten aan veel bijbelse teksten geven. Paas toont uit onvervalst gereformeerde hoek aan dat de verschillende concepten die door christen-zionisten worden aangedragen geen recht doen aan het diepste 'Anliegen' van de hele Bijbel. De Schrift zelf stuurt en corrigeert onze interpretatie en heeft het laatste woord. Zowel in het Oude als in het Nieuwe Testament blijft binnen de exegese Christus het primaat. Christus mag volgens de auteur niet gedecentraliseerd worden. 'For Christians Jesus Christ has become the crucial "hermeneutic glasses", i.e. Christians can read the holy Scriptures of Israel only from the perspective of God's revelation in Jesus Christ' (blz. 20). Wanneer binnen bepaalde christelijk-zionistische groeperingen de aantekeningen in de Scofield Bijbel bijna voor canoniek worden verklaard, dan is een heilzame correctie geboden (blz. 63).

Aan de hand van de geschiedenis neemt de auteur ons mee langs de verschillende opvattingen uit de Vroege Kerk, Middeleeuwen, Reformatie, Puritanisme, het Duits Christelijk Zionisme, de opkomst van de staat Israël en de periode na de Tweede Wereldoorlog. Duidelijk geeft hoofdstuk 5 (blz. 55-66) de verschillende richtingen aan binnen de vele radicale millenniumopvattingen. De auteur concludeert dat het Christelijk Zionisme gefaald heeft een veilige route te vinden tussen de kliffen van vijandelijke en enthousiaste fascinatie met de mensen, het land en de godsdienst van Israël.

Tegen de heersende Israëlopinie van veel kerkelijke kringen na de Tweede Wereldoorlog toont Paas aan dat de Schriften en de klassiek christelijke theologie een andere weg aanwijzen. Ook wordt hier aandacht gevraagd voor de zending, niet alleen onder de heidenen, maar ook in Israël.

De laatste zin van het boek spreekt dan ook voor zichzelf: 'Jerusalem and Tel Aviv are parts of the one mission-field, no less than Mecca and Amsterdam' (blz. 119). De kerk is geroepen om getuige te zijn van het heil en de genade in Christus Jezus.

De aanwezigheid van de zending in het Israël van vandaag en hoe dit concreet plaatsvindt blijft een zeer intrigerende vraag binnen de missiologie. Hoe verhouden zich het eigene van het spreken Gods tot Israël en de opdracht aan Zijn gemeente gegeven in de context van vandaag tot elkaar? Een omissie is het dat deze boeiende studie niet in gesprek gaat met vooraanstaande theologen die (vooral) in het naoorlogse Nederland door K.H. Miskotte en anderen het spreken over de positie van Israël weer op de kerkelijke agenda hebben gezet, en dat zodoende zelfs binnen de kerkenorde van de Protestantse Kerk in Nederland een plek heeft gekregen. Paas gaat voorbij aan de brede opvatting voor de blijvende aandacht die gevraagd wordt voor de speciale positie van Israël en de volle vervulling van Gods beloften aan dit volk gegeven voor de toekomst. Na zijn opmerking: 'The Church has not replaced Israel but represents its real meaning' (blz. 24), had een behandeling kunnen volgen hoe de auteur aankijkt tegen de heersende opvattingen binnen de kerk in het Koninkrijk der Nederlanden en binnen christelijk-zionistische kringen wereldwijd. 
Hopelijk krijgt deze studie een rechtmatige plaats binnen het circuit waar het debat over Israël gevoerd wordt en laat men Paas uitspreken. Hij heeft zeker niet het laatste woord over deze dingen, maar het Bijbels correctief dat hij in deze studie laat zien, is niet overbodig. Tegenover de overspannen Israëlfascinatie is deze studie duidelijk een correctief. Wat hier naar voren wordt gebracht verdient om gelezen en doordacht te worden. Het is prikkelend, stimulerend voor de een en nodigt uit tot tegenspraak van de ander. Het is hoog tijd dat de kerk om zaken die al eeuwenlang spelen tot de erkenning komt van Gods soevereine handelen met Zijn volk en over het geding dat Hij met dit volk heeft. Dit in blijvende verbondenheid met het Joodse volk aan wie de beloften Gods als eerste zijn gekomen en tot gehoorzaamheid van de christelijke kerk om het Evangelie van Jezus Christus te verkondigen, te beginnen in Jeruzalem tot aan de einden van de wereld. 